International Journal of Instruction e-ISSN: 1308-1470 • www.e-iji.net

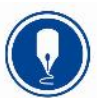

October $2018 \bullet$ Vol.11, No.4

p-ISSN: 1694-609X

pp. $761-776$

Received: $31 / 03 / 2018$

Revision: $21 / 07 / 2018$

Accepted: 26/07/2018

\title{
The Factors Affecting Teacher-Motivation
}

\author{
Neșe Börü \\ Asst. Prof., Nevsehir Haci Bektas Veli University, Turkey, nboru@ hotmail.com
}

$\mid$

The study aimed to provide an in-depth analysis of the internal and external causes that were influential towards job motivation of the teachers who were selected according to some success performance criteria for the institutions which is called science, art school where the gifted students are educated. The study was adopted as a qualitative research method and the case study was used. The data of the study were collected with semi-structured interviews. Content analysis method was used in analyzing the data. In accordance with the research aims, this study identified 2 themes and 7 sub-themes. 'Internal motivation resources' was determined as the first theme of the study. The subthemes under these themes like 'immaterial aims', 'success' and 'personal characteristics'. 'External motivation sources" was determined as the second theme of the study. The subthemes under these themes like 'students', 'national education policies' and 'school principals', 'colleagues'. In conclusion, participants were motivated with being successful, effective working condition, students' desire for learning, being more autonomous, equitable and consistent implementations regarding with project-based education approach.

Keywords: teachers, work-motivation, educational institutions for gifted students, teachers, motivation

\section{INTRODUCTION}

People are involved in educational processes for a variety of reasons, such as increasing their personal income, raising their living standards for higher levels, vocational concerns, intellectual development and social upbringing. Countries aim to increase the human capital power in society, to bring higher level of human development of the society, to increase the production potential of the country, to create the healthier and democratic society and to achieve sustainable development (Y1lmaz \& Sarpkaya, 2016, s.58). Individuals' educational needs are dispensable compared with their basic needs. However, each individual's educational expectation may differ. This situation may result in situation where the individuals can be reluctant to continue with the education process (Serin, 1979, p.17-18). In this context, teachers who are responsible for coping with student's diversity and limited opportunities, despite unfavorable environmental factors, should be taken into consideration keeping their own motivation in terms of sustainable development goals of the country.

Citation: Börü, N. (2018). The Factors Affecting Teacher-Motivation. International Journal of Instruction, 11(4), 761-776. https://doi.org/10.12973/iji.2018.11448a 
There is a general consensus that workers with feelings of resentment and exhaustion may have a low productivity or people's level of motivation effects on job's performance (Alıç, 1996, p.17). Motivation, on the other hand, stimulates people to change their behaviors, and make effort to sustain their endeavors in the direction of determined goals (Steers \& Porter, 1991; as cited, Riggio, 2014, p.189). Employees who are highly motivated to work are more likely to be productivity than those who are forced to do their jobs (Adair, 2003, p.94). The level of teachers' performance connects to their motivation, capacity and work conditions (Leithwood, 2006). In this context, researchers have developed various theories about human motivation and employee motivation that are effective in the performance of organizations. These theories will be discussed in the theoretical framework.

The teachers, who play an important role in the productivity and quality of the educational organizations, are humans rather than machines and also these directly serve the business of the country and develop the behaviors of the social life. Teachers in Turkey need to be supervised, rewarded and an effective career system. Turkey national ministry of education has a regulation for public school teaching position, which states as follow; all teachers can be employed under the exam regulation transition according to education faculties. According to the criteria of the staff, educational, scientific, cultural, artistic, sportive activities and central examination system, the teachers who start from teaching have the right to progress in national education career stages (Boyac1, 2016). It has not been organized in any exam for career stages about 10 years. Therefore, the teachers are waiting for their career steps. According to Ağaoğlu (2016); Turkish teachers in the national education system are audited by educational supervisors and school principals. There are more teachers and employees in the system. Educational supervisors have a lot of workload. The supervision of the teachers is left to the school principals hands. It is necessary to increase the knowledge of school principals on the audit and evaluation side. On the other hand, 'teachers' professional development' is accepted as the primary factor affecting school development and students' success (Canales \& Maldonado, 2018).

Determining the factors affecting their motivation is thought to be an important issue by the researchers. The nature of the relationships can be better understood using qualitative research designs. The current research aims to provide an in-depth analysis of the internal and external factors that are influential towards job motivation of the teachers who are selected according to their success performance criteria for the institution being science and art school where the gifted students are educated. So, this study would contribute with the opinions of distinguished teachers on work-motivation to the literature. Moreover, there are no enough results about the source of teacher motivations by using the qualitative research method. It can be reached the findings regards with the important and quality of project-based education and quality of the science and art school through opinions of the participants in the current research.

\section{Motivation theories}

Motivation leads people to act in order to reach their goals and to make efforts toward their aims. Some theories suggest that people's needs are influential on their motivations. 
According to these theories, their physiological and psychological needs can be the motivation source for people. According to Abraham Maslow's basic needs theory, the needs of individuals are eating, drinking, sexuality, marriage, security, love, compassion, friendship, recognition of achievements, appreciation and being respected. Clayton Alderfer made similar predictions for the individual's basic needs (Riggio, 2014, p.189-191). McCleand's human motivation theory (also known as Three Needs Theory puts emphasis on people's desire be successful, to have power and to relate to other people. Frederick Herzberg's two-factor theory within which he suggests that factors such as managerial quality, wages, business policies, physical working conditions and job security affect individuals' dissatisfaction towards work. The factors such as promotion possibilities, personal development, recognition, responsibility and success are seen as internal rewarding factors that are effective in motivating individuals. The theory of self-stability explains that external sources of motivation can be damaging to humans over time and the benefits of internal motivation. The goal setting theory suggests that having specific and difficult goals motivate people to improve their performance. The reinforcement theory of motivation assumes whether the outcome of behavior is being functional or not is important for individuals. Similarly, expectation theory claims that individuals expect to find the outcome of behavior effective and attractive. The theory of equality says that individuals react to inequality in the workplace. All these theories have been developed for adults living in the United States. The Cross-cultural changes of these theories may need to be taken into account (Robbins \& Judge, 2015, pp.208-229).

The elements that play a role in the management of the school can be divided into internal and external. Internal elements in the school can be considered as managers, teachers, students and other staff. External elements that affect the school from outside can be considered as parents, pressure groups, centralized management and labor market (Bursalığlu, 2002). In this context, internal and external sources of teacher's motivation can be evaluated according to internal and external elements of the school such as the personal expectations of the teachers, the quantities and qualities of the students, the school administrators' behaviors, the college behaviors, and the education policies.

The school principals play a major role in awakening the feelings among employees which in turn affect teacher's motivation (Tutum, 1979, p.184). Factors such as participation in the school administration, sharing of authority and responsibilities, competition, appreciation and reward, quality of work environment, educational opportunities and career development play a role in the motivation of teachers (Osmay, 2002, s.575). The communication skills and the school principals are also important in terms of teacher motivation. Teachers' communication is not only important for school administrators but also important for colleagues' motivation in schools. In short, intraschool relations are important for the morale of the teachers (Bingöl, 1984, p.29). The organizations which have an effective teamwork are less likely to leave the group because everyone acts towards the same direction. In an effective teamwork, difficult tasks such as leadership are carried out alternately. When one of the members of the 
team experiences any difficulties, the employees attach importance to team solidarity by supporting each other. The team also motivates each other to work (Sargut, 2015).

Education policies are the sum of the principles' laws and policies for the education system and the management of schools. The subjects of education policies can be the infrastructure value of the educational institutions, the size of the schools and classes, the privatization in education, the school preferences of the individuals, teacher's degree, teacher's employment, teacher salaries, education programs, teaching methods, and priorities in education (Aypay, 2016, s.168). The issues of education policies can be considered as external motivation sources that determine the internal and external elements of school administration and it moves teachers to work.

Teachers' salaries and the number of pupils per classroom can be one of the motivation factors according to motivation theories. In this context, the average number of students per teacher in OECD countries is between 10 and 20 for both primary education and lower secondary education; besides the student number in Turkey was approximately 20 in 2012. Thus, the number of students per teacher in Turkey is higher than the average of OECD countries and also the number of students per teacher in Turkey for upper secondary education is higher than the average of OECD countries (OECD, 2014). According to 2012 OECD reports, the salary of a newly started teacher in Turkey is $\$ 24,834$. The average of OECD countries is $\$ 29,411$. According to 2012 OECD reports, the salary of a teacher who had completed 15 years in Turkey was $\$ 26,678$. In summer the average of OECD countries was $\$ 39,024$ (Y1lmaz \& Sarpkaya, 2016).

\section{Review of literature}

According to the study of Thoonen et al. (2011, ss.516-521), the school' level of welfare working conditions, and the level of cooperation in school motivates teachers to improve their teaching activities. Collaboration in the school provides teachers with the opportunity to solve problems together, gaining feedback and information. Moreover, teachers encourage the use of new materials in class, experimenting new things, which reflects current teaching and comprehensiveness of any given class. Collaboration in school provides support to teachers and triggers professional cultures and increases teachers' tolerance in ambiguity. Confidence in the school can also affect teachers' prosperity and level of cooperation in the school. However, confidence in the school can negatively affect teacher motivation and teacher professionalism. Excessive confidence moderates the influence of organizational factors and leadership behaviors. Transformative school leadership also influences teacher's motivation, and motivates them to get involved in professional learning activities. Teachers are reluctant to be involved in the process of building the vision of the school. If teachers are experiencing job satisfaction with teaching activities in the class, their willingness to participate in extracurricular activities becomes lower. The school principals respect that teachers do not participate in the decision-making process related to school. Teachers can regard this situation as a non-verbal agreement.

According to the study of Karaköse \& Kocabaş (2006), teachers working in private schools have a more positive perception of their motivations regarding the attitudes and behaviors of school principals than teachers working in public schools such as valuation 
of the opinions and the appreciation by school principals. Similar findings are valid within their profession prestige. On the other hand, private school teachers experience more stress in their jobs. Appreciation of teachers and valuation of teachers' opinions are considered by the results of the past researches (Özgan \& Aslan, 2008; Öztürk \& Dündar, 2003; Barlı et al., 2005). The findings of Öztürk \& Dündar (2003) reveal the importance of courtesy in the communication. However, according to Barl et al. (2005), the physical conditions of the school and the cooperation between colleagues positively affect teachers' work-motivation. In the study of Bishay (1996); results have shown that teachers liked teaching more than any other profession. Besides, the socialization of some colleagues' field is not as important for others and neither does it intimidate them when it comes to job-satisfaction. Research suggests that teachers are highly satisfied with their occupations. However, this result contradicts with a past study where teachers work with selective chosen individual students rather than all students. For instance, successful classroom discussions and class size reduction would help promote the jobsatisfaction. The result shows that gratification of higher-order need is the most important one. However, young teachers were not satisfied with their incomes according to this study. While satisfaction seems more correlated with personal factors than environmental factors, environmental factors are not excluded. The atmosphere rewards paperwork, which affects teachers' motivation negatively or positively. For example, atmosphere is important for science and math teachers as well as rewards are important for older teachers without being told that women find paperwork burdensome. When we look at the past literature, it can be thought that teacher give an importance to internal factors more that external factors except school environment.

\section{METHOD}

This research was designed as the phenomenology approach based on qualitative research method. The phenomenology approach aims to take an in-depth and detail view of what we have noticed as facts. Events may exist with different occurrences such as experiences, perceptions, concepts and situations (Yıldırım \& Şimşek, 2006, p.72). Phenomenological study tries to acknowledge perceptions, perspectives and understandings of people related to a particular event through in-depth and unstructured interviews. The sample size generally ranges from 5 to 25 individuals (Leedy \& Ormrod, 2001). The subject of the current research is to determine the factors affecting the motivation of the teachers working in the Turkish national schools where gifted students are educated. In relation to this subject, the study aims to acquire comprehensive, in-depth and systematic information on experiences and perceptions of teachers on work-motivation.

\section{Participants}

The extreme or deviant case sampling is used in the current study. The extreme or deviant case sampling is taken into consideration special or unusual cases such as outstanding success or notable failures because these kinds of cases may be rich in terms of information (Patton, 2014, p.230). The participants of the research were teachers who were in charge of an institution that applied educational activities for gifted students during the academic year 2016-2017. The teachers of this school were selected 
according to some criteria such as the level of education by Turkish National Education Ministry because the qualified teachers were necessary for this school's students. Therefore, these participants can be accepted as successful because of their performance or having high academic degrees. The level of education of participants is accepted as outstanding success for the purposes of the current research because this characteristic of participants is not common in Turkish national education schools. Table 1 contains information on participants' code, gender, age, seniority, the level of education and professional field.

Table 1

Demographic characteristics of participants

\begin{tabular}{llllll}
\hline Code & Gender & Age & Seniority $^{1}$ & The level of education & Professional field \\
\hline P1 & Woman & 31 & 9 & PhD student & Maths \\
P2 & Man & 35 & 15 & Bachelor & Music \\
P3 & Woman & 31 & 10 & PhD student & English language \\
P4 & Woman & 31 & 5 & Master student & Primary teacher \\
P5 & Man & 32 & 5 & PhD student & Arts \\
P6 & Man & 35 & 12 & Master degree & Chemistry \\
P7 & Man & 33 & 7 & Bachelor & Turkish language \\
P8 & Woman & 27 & 44 & PhD degree & Physic \\
P9 & Man & 39 & 15 & Master degree & Maths \\
P10 & Man & 45 & 19 & Master degree & School counselor \\
P11 & Man & 34 & 13 & Master student & History \\
P12 & Man & 39 & 17 & Master degree & Science \\
P13 & Woman & 34 & 13 & Master degree & English language \\
P14 & Man & 35 & 13 & Master degree & Turkish language \\
\hline
\end{tabular}

\section{Data Collection and Instruments}

A semi-structured interview technique, which is the leading data collection tool in the phenomenological studies, has been used to collect the data of the study (Y1ldirim \& Şimşek, 2006, p. 74; Leedy \& Ormrod, 2001). The questions of the study were prepared as 'an interview form' about the factors affecting the motivation of the teachers. This interview form consists of two parts: demographic characteristics and interview questions. The interview questions were prepared according to previous studied that aimed to determine the factors affecting teacher motivation. Interview questions consist of a total of 11 open-ended questions. Interview questions are placed in appendixes. Participants were allowed to have a quick glance at the interview questions before the interview. During the interview, the participants were asked further questions to collect more in-depth data. The researcher developed a communication process based on trust and empathy with the research participants.

\section{Data Analysis}

In the analysis of the data obtained at the end of this study, the inductive analysis approach was used to analyze the data obtained. The stages of the inductive analysis

\footnotetext{
${ }^{1}$ Length of service
} 
approach were taken into consideration (Yıldırım \& Şimşek (2006, pp. 228-240). These stages include:

Coding of the data: The obtained data are divided into broad sections. These sections can be words, sentences, paragraphs or pages and each section is conceptually understood and encoded. Finding the themes: The codes obtained are categorized. Each set of categorized code bundles is a subject to encode as a theme and each theme points out their general case. Organizing and defining data according to codes and themes: Themes, categories and codes are presented and explained in a system that the reader can understand. Interpretation of findings: At this stage, themes, categories and codes, which are presented in a particular system are discussed and interpreted by the researcher, and some conclusions are drawn.

\section{Reliability and Validity}

Validation of the study was based on validity strategies that should be used in the qualitative studies mentioned in Christensen et al. (2011). In order to ensure the theoretical validity of the study, a theory diversification method was applied and the consistency between the theory and the data was provided. The prepared questions were presented to the field experts together with the research problem. The necessary corrections were made based on the views of the field experts and a pilot interview was held with a volunteer teacher to test the clarity and the internal validity of the questions. In addition, during the collection of the data of the participants, follow-up probing questions were asked as much as possible and the participants were asked to express their opinions in greater detail. Verbatim comments have been included in the process of making sense of the findings. The results obtained at the end of the research and the comments made by the participants were checked to ensure the interpretation validity. The process of analysis and interpretation of the data were supported by findings obtained from the past research in the field. At the end of this study, the reliability is calculated by using the formula Reliability = Opinion Union / (Opinion Union + Opinion Separation) formula. The numbers of 'Opinion Union' and 'Opinion Separation' are determined from the researcher and an expert. Over $70 \%$ of the reliability calculations were considered reliable (Miles \& Huberman, 1994, p.64). According to this calculation, the reliability was found as 0,81 .

\section{FINDINGS}

As a result of the coding of the data obtained at the end of the research, the following 2 themes and 7 sub-themes were found. (1) Internal motivation resources: Under the first theme, 3 sub-themes were found: (a) immaterial aims, (b) success, (c) personal characteristics. (2) External motivation sources: Under the first theme, 4 sub-themes were found: (a) students, (b) national education policies, (c) school principals and (d) colleagues.

\section{Internal motivation resources \\ Immaterial aims}

The codes determined in relation to the "immaterial aims" sub-theme of the research are 'to recompense the salary', 'conscience', 'professional love', 'country love', 'teaching 
love', 'human love', 'self-sacrifice' and 'idealism'. Direct quotations that attract the researcher's attention about immaterial aims are in the following paragraphs.

As for the code of "to recompense the salary ", P7 said that "Why? Because I am being paid a fee for this. Who am I to say that I need to really fulfill the requirements of my job? I'm trying to do my best". As for the code of "country love", P12 said that "I am here because of the Battle of Gallipoli. It is very rare in history, it is not even the same. I think a war like the Battle of Gallipoli is not even the same because the Gallipoli War was not an ordinary war and it was not a war of nations, either. If you can save today, you better start acting now. I always looked around and say. I love this country very much. I mean, by the way, I am from Diyarbakir."

\section{Success}

'Wanting to be succeed', 'do not like monotonous', 'having goals', 'national and international awards' and 'the desire to become a popular teacher' determine the "success" sub-theme of the study. Direct quotations that attract the researcher's attention about success are in the following paragraphs.

As for the codes of "do not like monotonous" said the P1 "We have a lot of activities outside of the institution, and our visitors have the opportunity to see many things on the spot, as institutional. In that sense, it is also enjoyable because there are so many things to explore, for example; in science fairs for children, two weeks ago we went to visit the mathematics village. Generally, we invite our college students to visit the history of mathematics so that it may boost their interest on the subject like math. ...We compare it with the other schools, they do not like that. This kind of activities are very constructive for students." Participants of the study are considered to be more successful than the other teachers working in the National Ministry of Education because they are selected according to a set of criteria for the schools where the gifted students are educated. The participants of the research are all masters, doctoral students or graduates. These codes, which are under the sub-themes of the main theme success, are in line with the graduation level of the participants.

\section{Personal characteristics}

The codes identified in relation to the sub-theme of the survey's "personal characteristics" are 'do not give up', 'to love learning 'perfectionism' and 'perseverance'. Direct quotations that attract the researcher's attention about personal characteristics are in the following paragraphs.

As for the codes of "Do not give up", P5 said that "In my opinion. Not to give up in every case. The Turkish teacher does not have the luxury of being unsuccessful'. Guess why? Because we have to be successful, failure for our society is a luxury, as well as making a mistake a luxury." The codes under this sub-theme can also indicate that all participants of the research were master, Ph.D. students or graduates.

\section{External sources of motivation}

\section{Students}

The codes determined in relation to the sub-theme of the research 'students' are 'the level of students' success', 'students' request for learning' and 'students' productivity'. 
Participants in the current research are usually referred to in the code of "Students' request for learning". The finding is about the importance of the approach of projectbased on education and interest of students in lectures in terms of teachers' motivation. Teachers have found out that in schools where trains gifted students use the education approach to make projects are more motivated than in schools where they use conventional methods. Therefore, some participants are very content with making projects with gifted students.

With regard to the code of "students' request for learning", P2 said that "Now, I am working in the school of gifted students. I worked in a High School before, and I am working with five percent and ten percent of my performance. I am currently working over the percentage of fifty. We can say eighty percent performance. I can use my university's information; I could not use any of this information in normal high school, elementary school. ... Why is not there? Because ninety-five percent of the students come to the school with university entrance exam anxiety, they do not get involved in arts-related activities. Even if they have the talent, they prefer to stay away from it. I mean ... I mean, I would like to say ... I'm expressing myself here." The codes under this sub-theme may be related to teachers' desire to succeed. Teachers want to see the result on time and energy they spend. They are aware that this success will not be possible without academic discipline and the help of teacher.

\section{National education policies}

The codes determined in relation to the sub-theme of the research "national education policies" are 'class size', 'the physical conditions of the school', 'the requirement of course materials', 'working hours', 'curriculum', 'accountability', 'quality in in-service training', 'the requirement of ethic in project evaluation process', 'the importance of institutions' the independence by away from political authorities', 'project-based education approach' and 'test-based examination system'. Direct quotations that attract the researcher's attention about national education policies are in the following paragraphs.

Regarding the codes of "the requirement of course materials" and "the physical conditions of the school" P5 said that "...the school training gifted students is more relaxed because the school meets the material and gives an art studio. But at the other public school, the student should bring material. This often causes difficulties. Apart from that, you do not have an art studio, most schools already have classroom problems."

As for "project-based education approach", P14 said that "I'm excited about projectbased education system. We talk about videos, documentaries, games, but intelligence games. This is more fun, so none of them are in other institutions. ". As for the code of "quality in project-based education" P6 said that "There are hundred schools where the gifted students are educated in Turkey. How many problems have been solved? Now everyone in National Education wants to do projects. Everyone may do some bulb experiments, but there is no benefit for us in doing it. So instead of producing ten million projects, we produce ten projects, and they get qualified. TÜBITAK (The 
Scientific and Technological Research Council of Turkey) awards project every year. And when looking at any of the project none of them are patented." As for "test-based examination system", P13 said that "For me, that test system is the test system that National Education generally applies to students, I should not apply very much. Why? Because there is no exam at school for gifted students and the students come running here. The school focuses on activities, experiments and they learn by doing and living. Therefore, this already increases the personal satisfaction of the children and makes them love business. In fact, I think the exam system affects the motivation and the children's motivation"

As for "accountability concern", P10 said that "We are a democratic structure, but ultimately we have an authoritarian system. As a result, for example, you always have to give an account. This may mean paperwork on business. So you need to constantly present something to the people at higher statue.". About the code of "class size" P7 said that "We have a chance to get to know the students individually at school training gifted students because of minimum class size, and we have a chance to deal with them individually. This makes the work much easier and enjoyable for both teacher and students.". Relating to the code of "Curriculum" P9 said that "I have covered the curriculum in other school but at the school training gifted students, I am free because there is no more curriculum here. There's a lot of work to do. You can do trips, workshops, robotics, competitions, and lots of different things, so it's more flexible here..." Participants expressed their view that national education policies affect their job motivation negatively. Participants attach an importance to professional progress but they emphasize the insufficient functions of education policies in achieving the main goal. Further research is needed to generalize the views expressed in this respect.

\section{School principals}

The codes determined in relation to the sub-theme of the 'school principals' of the research are 'valuation of ideas', 'fairness', 'equality', 'persuasion skills', 'the power to motivate teachers', 'problem solving skills', 'openness to criticism', 'discretion', 'tolerance', 'empathy', 'kindness', 'soft words', 'effective listening process', 'respect', 'horizontal hierarchy'. Direct quotations that attract the researcher's attention about school principals are in the following paragraphs.

As for the code "valuation of ideas", P12 said that "For example, I do not make student projects, never do I prepare projects for students. It is my job to teach the student how to make the project. And not to prepare project for them...but often times my principal tells me to, prepare the projects so therefore I lose my focus sometimes because it seems like I don't know the school's regulations.". As for the code "being objective", P13 said that "We have to be in contact with more administrators at the school training gifted school. The attitude of administrators is important for us in this sense because, we have been doing projects and for them a serious team spirit is needed. In this case, I really questioned how the attitudes and behaviors of the administrators should be. I think that they should react as if they should evaluate the events with an objective point of view. The responsibilities should be shared and a team decision is needed, as well as common decision." 
As for the code "kindness" and "respect", P2 said that "24th November, Teacher's Day is approaching. The District National Education Director called me. If you are appointed as a music teacher, you are subjected to make a chorus for the Teacher's day... I said, there are three to four days ahead of the event. I do not know children, I won't it, I said to the principle but then ... He said that 'you will teach like a donkey.' I didn't reply or even make any sound since ... I was new. I am twenty-one years old." The codes contained in this sub-theme are related to the characteristics of school administrators. These characteristics are similar to the leadership behaviors expected from school administrators.

\section{Colleagues}

The codes identified in relation to the sub-theme of the research 'colleagues' are 'synergy', 'equal distribution of tasks', 'collaboration', 'solidarity', 'friendly competition'. Direct quotations that attract the researcher's attention about colleagues are in the following paragraphs.

As for the code "friendly competition", P4 said that "Of course, when you see your friends and see that they are constantly dealing with something new, you also try to do more, and better and even do some investigation. Of course if you see that people around you are constantly sitting, it's not encouragable, I like competition as long as it is friendly. It's through competition that bring the students higher level up and I am always looking for such creative competitions." P13 said regarding "collaboration" that "Let's imagine if I had written twenty examples on the board and wanted all the student to go to the board to practice, it would be a mess. So, all I am saying is that it is not possible to find a suitable environment for such collaboration in every school. The codes under this sub-theme related to the characteristics that participants expect from their colleagues. These codes show the importance of the cooperation in the schools.

\section{DISCUSSION \& CONCLUSION}

According to Locke (1968), the goal of setting theory is to have positive results on their performances (Robbins and Judge, 2015, p.208-229) because people want to be successful in reaching their ultimate goals. According to Maslow's theory of hierarchy of needs and the theory of Alderfer (Riggio, 2014, p.190-191), the theory of McCleand and the theory of Herzberg (Robbins and Judge, 2015, p.208-229); the desire to be successful is an important factor that motivates people to work. According to the findings of the current study, the codes, which are related to success, immaterial aims and personal characteristics, stand out as internal factors affecting teacher motivation. People take into factors that 'desire of wanting to succeed', 'having goals', 'awards' account besides factors such as 'conscience', 'country love' and 'professional love'. The participants of the current study have master $/ \mathrm{PhD}$ degree or master/PhD student. The characteristic of participants is in line with code 'wanting to be succeed', 'do not like monotonous', 'having goals', 'national and international awards' and 'the desire to become a popular teacher'. These findings are similar with the claims of goal setting theory and expectation theory. 
Students, national education policies, school principals, colleagues can be considered as external factors affecting teacher work motivation according to the present study. It can be considered that these external sources can positively influence the internal motivation based on the teachers' success and immaterial aims. These external factors according to the current research include:

- Students' level of perception and learning desire: Bishay's (1996) study found that job satisfaction and job motivation are high for teachers working at schools where successful students are educated. The study of Atkinson (2000) also jibes with the findings. Participants in the present study also work at the school where the selected students are educated. Some participants at times are motivated by observing the students engaged in the subjects or activities.

- Principals' fairness and communication skills of principals: In this study, the characteristics related to the administration, justice and communication skills of school administrators, which have positive effects on teacher motivation, have been reached. Akman, (2018), Thoonen et al.'s (2011) research suggests that leadership skills of school principals positively influence teachers' job motivation. The findings of Öztürk \& Dündar, (2003), Doğan \& Koçak, (2014) and Yaman et al., (2010) reveal the importance of courtesy in the communication.

- Colleague attitudes and behaviors have resulted as the solidarity and the synergy in school. Kiran \& Sungur, (2018), Sargut, (2015); Thoonen et al., (2011); Yaman et al., (2010); Bishay, (1996); Bingöl, (1984) studies also show that the effectiveness of cooperation in schools or teachers solidarity have a positive effect on teachers' job motivation.

- Education policies that support teacher and student creativity such as implementing 'project-based education approach' and being far away from 'test-based examination system'.

- Quality of the school's physical conditions and course materials

Teachers may accept these items as auxiliary forces that lead them to success. Teachers are employees who have to deal with students' diversity. In this diversity, it is probable that the students are reluctant to learn. Therefore, teachers are responsible for overcoming the problem of students' reluctance; they have to handle some problems caused by factors such as quality of principals, synergy in school, quality of education policy and qualified material opportunities. The qualified characteristics of schools are quite important in the motivation of teachers who have a key role in shaping the future of society.

Expectancy value theory argues that results and attractiveness of the behavior affect the behavior of individuals (Robbins and Judge, 2015, p.208-229). In this context, when the findings of the current research are examined, teachers expect to win national and international awards, success of their students and appreciation of principals for their opinions or their success. According to the findings of the current research, when the expectations of the teachers regarding the sources of external motivation such as rewards and wages are evaluated, they want only better working hours and appreciation of principals. Participants do not comment on their economic conditions, which could 
affect their motivation. Sinclair's (2008) study found that student teachers had more likely internally referenced rather than externally referenced motivations for teaching and elaborating the importance of 'working conditions' for student teachers. According to Bishay's (1996) study, while there are high expectations of teachers in general, young teachers find their salaries insufficient. While personal factors affect teachers' job motivation more, the importance of external factors is not negated. This conclusion can be accepted as similar with the current research's conclusion. Bandura's the theory of self-efficacy has stated the benefits of internal motivation can be impaired in humans over time (Robbins and Judge, 2015, p.208-229). The majority participants of the current study have master and doctoral degree. In this context, it is possible to mention the existence of a consistent relationship between participants' expectations and educational levels.

The codes related to valuation of the opinions and the appreciation by school principals are taken into consideration in the findings of the studies of Thoonen et al.'s (2008), Özgan \& Aslan's (2008), Karaköse \& Kocabaş's (2006), Barlı et al.'s, (2005) and Öztürk \& Dündar's (2003). The code of kindness matches up with the findings in the studies of Özgan and Aslan's (2008). The theory of equality says that discrimination against employees at work affects employees' motivation negatively (Robbins and Judge, 2015, p.208-229). The participants of the study state codes related to fairness and equality under the sub-theme of school principals. Arts and music teachers complain being a negative perception, which is about trivializing their lessons developed by people and policies. This perception can be accepted as inequality in terms of arts and music teachers. Therefore, improvement works related to the situation can be done.

The codes related to national education policies are considered as one of the external motivational factors affecting teacher motivation in this research, teachers expect the minimum class size. Bishay's (1996) study also shows that class size positively influences teacher motivation. Teachers also wish to have autonomy on education curriculums. The study of Atkinson (2000) also overlaps with the finding. They also state the importance of institutions' the independence by away from political authorities and emphasis on the importance of selection of school principals with qualifications. The codes of 'test-based on examination system', 'the school administration's publicity concerns' and 'the weakness of authority of the teacher and the power of authority of parents' adversely affect the teachers' prestige. According to Maslow's, Alderfer's, and Frederick's motivation theory, individuals desire to be respected and well known (Riggio, 2014, p.190-191), their profession prestige was also taken into consideration in the findings of the studies of Karaköse and Kocabaş, (2006).

Teachers expressed the positive effect of project-based on education rather than testbased on their motivation. The opinion resemble with the findings of Lam et al. (2010) They emphasize the importance of quality in project-based on education, ethics in the project evaluation process and inconsistent issues in the national education system. More research is needed to explore views of teachers about project-based education. According to these studies, improvement works can be developed for the national education system. 
The code related to teachers' concern is the main concern for accountability to senior management. In this context, new studies can be done about why teachers are worried about giving accounts to administrators. The code of the qualification in service training may show the importance of humanity in teaching. On the other hand, teachers do not talk about teacher salaries. New studies can be done related to the opinions of teachers about salary satisfaction. The codes such as physical conditions of the school, cleaning, school equipment and course materials are similar with the findings of the studies of Barlı et al. (2005). The codes of solidarity and peace between colleagues were also taken into account both in the present study and the study of Barlı et al. (2005). For the improvement of the physical conditions of the school, administrators can make every effort to find donation.

To the degree to which participants willingly took part in the study; the attitude participants had toward school principals and the government; the fear of teacher not wanting to remembered to indulgence of material things because of seeming teacher profession as a sacrifice can be accept as possible limitations

In conclusion, the most basic source of motivation for the teachers involved in the research is their desire to be successful and their immaterial aims feelings. However, the current school policies and students', school principals', colleagues' attitudes and behaviors influence being successful in the teaching profession. Participants expect to be more autonomous in managing their curriculum and course times. They also want to implement project-based education approach. Yet, teachers report that inconsistent and unjust approaches of the national education policies regarding with project-based education approach negatively affect the teachers' motivations. While teachers are waiting the institution to be more democratic by asking for the independence from political authorities, they feel tension in accountability, which is considered to serve function of a more democratic institution. Future research can be conducted on the root causes of why teachers are not motivated to be accountable because the small sample of this study does not allow for generalizability of findings discussed throughout this study.

\section{REFERENCES}

Adair, J. (2003). Etkili motivasyon. İstanbul: Kültür Yayıncılığı.

Ağaoğlu, E. (2012). Türk eğitim sistemi ve okul yönetimi. In S. Özdemir \& T. Çalık (Eds), Okul yöneticilerinin denetim ve değerlendirme rolü. Pegem Akademi.

Akman, Y. (2018). Investigating the Relationship between Organizational Justice, Work Motivation and Teacher Performance. Cukurova University Faculty of Education Journal, 47(1).

Alıç, M. (1996). Eğitim sisteminin amaçlarının gerçekleştirilmesinde eğitim yöneticisinin işlevleri [The functions of educational administrator in realizing the aims of the educational system]. Çăgdaş Ĕ̈itim, 21(217), 14-17.

Atkinson, E. S. (2000). An investigation into the relationship between teacher motivation and pupil motivation. Educational Psychology, 20(1), 45-57.

Aypay, A. (2016). Ĕgitim politikası. Ankara: Pegem A 
Barlı, Ö., Bilgili, B., Çelik, S., \& Bayrakçeken, S. (2005). İlköğretim okul öğretmenlerinin motivasyonları: farklılıkların ve sorunların araştırılması. Atatürk Üniversitesi Sosyal Bilimler Enstitüsü Dergisi, 5(1).

Bingöl, D. (1984). Çalışma psikolojisi. Erzurum: Atatürk Üniversitesi İ.İ.B.F. Yayınları.șẹp]

Bishay, A. (1996). Teacher motivation and job satisfaction: A study employing the experience sampling method. Journal of Undergraduate Sciences, 3(3), 147-155.

Bolman ve Deal, (2008). Organizasyonları yeniden yapılandırmak. Ankara: Seçkin Yayıncılık.

Boyac1, A. (2012). Türk eğitim sistemi ve okul yönetimi. In S. Özdemir \& T. Çalık (Eds), Okullarda insan kaynağının yönetimi. Pegem Akademi.

Bursalığlu, Z. (2002). Okul yönetiminde yeni yapı ve davranış. Ankara: Pegem A Yayıncılık.

Canales, A., \& Maldonado, L. (2018). Teacher quality and student achievement in Chile: Linking teachers' contribution and observable characteristics. International Journal of Educational Development, 60, 33-50.

Christensen, L.B., Johnson, B., Turner, L.A. (2011). Research methods, design, and analysis.

Doğan, S., \& Koçak, O. (2014). Okul yöneticilerinin sosyal iletişim becerileri ile öğretmenlerin motivasyon düzeyleri arasındaki ilişki. Kuram ve Uygulamada Egitim Yönetimi Dergisi, 20(2), 191-216.

Karaköse, T., Kocabaş, İ. (2006). Özel ve devlet okullarında ögrretmenlerin beklentilerinin iş doyumu ve motivasyon üzerine etkileri. Eğitimde Kuram ve Uygulama, 2(1); 3-14

Kıran, D., \& Sungur, S. (2018). Fen Bilimleri Öğretmenlerinin Motivasyon ve İş Doyumlarının Okul Ortamı ile İlişkisi. Eğitim ve Bilim, 43(194).

Lam, S. F., Cheng, R. W. Y., \& Choy, H. C. (2010). School support and teacher motivation to implement project-based learning. Learning and Instruction, 20(6), 487-497.

Leedy, P. D., \& Ormrod, J. E. (2001). Practical research: Planning and research. Upper Saddle River, NJ: Merrill.

Leithwood, K. (2006). Teacher Working Conditions that Matter: Evidence for Change. Toronto, ON: Elementary Teachers' Federation of Ontario.

Locke, E. A. (1968). Toward a theory of task motivation and incentives. Organizational behavior and human performance, 3(2), 157-189.

Miles, M. B., \& Huberman, A. M. (1994). Qualitative data analysis: An expanded sourcebook. Sage.

OECD (2014), Education at a Glance 2014: OECD Indicators. OECD Publishing. http://dx.doi.org/10.1787/eag-2014-en

Osmay, N., 2002. Insan mühendisliği. İstanbul: Alfa Yayınları.

Özgan, H. ve Aslan, N. (2008). İlköğretim okul müdürlerinin sözlü iletişim biçiminin ögretmenlerin motivasyonuna etkisinin incelenmesi. Gaziantep Üniversitesi Sosyal Bilimler Dergisi, 7(1), 190-206.

Öztürk, Z., Dündar, H. (2003). Örgütsel motivasyon ve kamu çalışanlarını motive eden faktörler. Çukurova Üniversitesi İktisadi ve İdari Bilimler Fakültesi Dergisi. 4(2); 57-66.

Patton, M. Q. (2014). Nitel araştırma ve değerlendirme yöntemleri. Ankara: Pegem Akademi.

Riggio, R.E. (2014). Endüstri ve örgüt psikolojisine giriş. Ankara: Nobel Yayınc1lık. 
Robbins, S.P. ve Judge, T.A. (2015). Örgütsel davranış. Ankara: Nobel Yayıncılık.

Sargut, A. S. (2015). Lider Yöneticinin Benliğine Yolculuk. İstanbul: Beta.

Serin, N. (1979). Ĕgitim ekonomisi. Ankara: Ankara Üniversitesi Basımevi.

Sinclair, C. (2008). Initial and changing student teacher motivation and commitment to teaching. Asia-Pacific Journal of Teacher Education, 36(2), 79-104.

Steers, R. M., and Lyman W. Porter, (1991). Motivation and work behavior. New York: McGraw-Hill.

Thoonen, E. E., Sleegers, P. J., Oort, F. J., Peetsma, T. T., \& Geijsel, F. P. (2011). How to improve teaching practices: The role of teacher motivation, organizational factors, and leadership practices. Educational Administration Quarterly, 47(3), 496-536.

Tutum, C. (1979). Personel yönetimi. Ankara: TODAİ Yayınlar1.s[ّẹ:

Yaman, E., Vidinlioğlu, Ö., \& Çitemel, N. (2010). İşyerinde psikoşiddet, motivasyon ve huzur: Öğretmenler çok şey mi bekliyor? Psikoşiddet mağduru öğretmenler üzerine. Uluslararası İnsan Bilimleri Dergisi, 7(1), 1136-1151.

Yıldırım, A., \& Şimşek, H. (2006). Sosyal bilimlerde nitel arastirma yöntemleri. Seçkin yayıncilik.

Yılmaz, T., \& Sarpkaya, R. (2016). Eğitim ekonomisi: Eleştirel bir yaklaşım. Anı Yayıncılık, Ankara.

\section{APPENDIXES}

Interview questions

1.What are the internal factors that motivate you in working for school aims?

a. Personal characteristics

b. Senses

c. The structure of idea

d. Believes

e. Experiences

2. What are the effects of the attitudes and behaviors of your school principal?

a. Communication skills

b. Appreciating teachers skills

c. Trust

d. Justice

e. Leadership skills

3. What are the effects of your colleagues on your motivation?

4. What is the effect of the social environment on your motivation?

5 . What are the effects of students on your motivation?

6. What are the effects of the school that you're still working for on your motivation?

a. Does the type of school affect on your work-motivation level to serve school's goals?, How?

7. How do qualifications of national education policies affect you on your work-motivation level to serve school's goals?

8. What are the situations that hinder your motivation on your job? 